Damian OTTA

Chojnickie Stowarzyszenie Miłośników Kolei

\title{
TURYSTYKA KOLEJOWA W WOJEWÓDZTWIE POMORSKIM
}

\section{Wprowadzenie}

Turystyka definiowana jest jako „wyjazdy poza miejsce stałego zamieszkania w czasie wolnym od pracy w celach wypoczynkowych, poznawczych lub związanych $\mathrm{z}$ indywidualnymi zamiłowaniami oraz użytkowania środowiska celem zaspokajania potrzeb przebywających w nim turystów" (Rogalewski, 1974, s. 7). Turystyka jest zatem ściśle powiązana ze zmianą miejsca pobytu, co wpisuje się w definicję transportu, rozumianego jako przemieszczanie osób lub przedmiotów z jednego miejsca do innego (Tarski, 1973). Jednym z najpopularniejszych środków transportu pasażerskiego jest kolej. Już na etapie definicji można zauważyć korelację między turystyką a koleją.

Pojęcie turystyki kolejowej można interpretować dwojako, w zależności od tego, czy kolej jest traktowana jedynie jako środek transportu, czy też przejazd pociągiem jest głównym celem migracji turystycznej (Górny, 2014). W pierwszym przypadku, gdy kolej wybierana jest jako środek lokomocji, za pomocą którego turysta przemieszcza się, lecz podstawowym celem wyjazdu nie jest ani przejazd pociągiem ani kontakt $\mathrm{z}$ walorami kolejowymi, rozumie się jako turystykę koleją. W drugim przypadku sam przejazd pojazdem kolejowym (niekoniecznie pociągiem), lub odwiedzanie miejsc związanych z koleją jest głównym celem migracji (Górski, 2014). Mimo iż w literaturze tematyka turystyki kolejowej nie jest często opisywana, na podstawie własnych doświadczeń i obserwacji dokonano nieco bliższej charakterystyki pojęcia. W turystyce kolejowej wydzielić można kilka różniących się motywacją rodzajów podróży. W pierwszym podstawowym wariancie celem podróży jest przejazd pociągiem, będący 
główną atrakcją dla turysty, zaliczającego się najczęściej do grona miłośników kolei. Dla części pasjonatów dodatkową motywacją jest chęć przebycia szlaku, a więc przejazd pociągiem po danej linii kolejowej. Wzmożony ruch tego typu turystów zauważalny jest w momencie, gdy przewoźnicy uruchamiają nowe bądź okazjonalne połączenia na liniach kolejowych, które w ostatnim czasie nie były wykorzystywane w ruchu pociągów pasażerskich. Udział w przejeździe pociągu specjalnego, który pokona czasem jedynie kilkukilometrowy dystans po nieczynnej na co dzień linii kolejowej, staje się dla miłośników motywacją do odbycia wielogodzinnej podróży celem skorzystania z pojawiającej się okazji turystycznej. W kolejnym wariancie turystyki kolejowej najważniejszym czynnikiem wpływającym na podjęcie decyzji o migracji turystycznej jest tabor kolejowy. Najczęściej motywację stanowi sentymentalny przejazd pociągiem zestawionym z taboru, który obecnie nie jest już wykorzystywany w ruchu pasażerskim lub jest używany sporadycznie w niektórych regionach. Sztandarowy przykład to wykorzystanie w trakcie przejazdu trakcji parowej, lecz coraz częściej także trakcji spalinowej w zestawieniu ze starymi typami wagonów pasażerskich. Kolejną formą turystyki kolejowej jest zwiedzanie muzeów, skansenów taboru kolejowego i izb tradycji kolejowej, związanych z historią kolejnictwa. Coraz częściej organizuje się również zwiedzanie czynnych lokomotywowni i zapleczy technicznych przewoźników kolejowych w połączeniu z wystawami taboru kolejowego przy okazji obchodów, np. dnia dziecka lub dni techniki. Innym aspektem turystyki kolejowej jest odwiedzanie miejsc historycznie związanych z kolejnictwem, takich jak: dworce i stacje kolejowe, obiekty inżynieryjne (mosty, wiadukty, tunele), urządzenia (obrotnice, zapadnie, zwrotnice), obiekty kubaturowe (nastawnie, hale napraw), a także obiekty często opuszczone i niewykorzystywane obecnie w prowadzeniu ruchu kolejowego lub zaadaptowane do innych celów. Szczególną formą tego typu aktywności jest przemierzanie ciągów nieczynnych bądź zlikwidowanych linii kolejowych - pieszo lub na rowerze po wybudowanych w miejscu torowisk ścieżkach rowerowych. Coraz większą popularnością cieszą się również przejazdy drezynami po nieczynnych liniach kolejowych.

\section{Sieć kolejowa}

Przed II wojną światową województwo pomorskie posiadało gęstą sieć linii kolejowych, dzięki której można było dojechać pociągiem do niemal wszystkich większych ośrodków miejskich. Niestety w wyniku działań wo- 
jennych oraz przemian gospodarczych na przełomie XX i XXI w. sieć ta została znacznie uszczuplona. Na rysunku 1 przedstawiono mape linii kolejowych na terenie województwa pomorskiego, z podziałem na linie czynne i nieczynne $\mathrm{w}$ ruchu pasażerskim oraz nieistniejące już szlaki kolejowe.

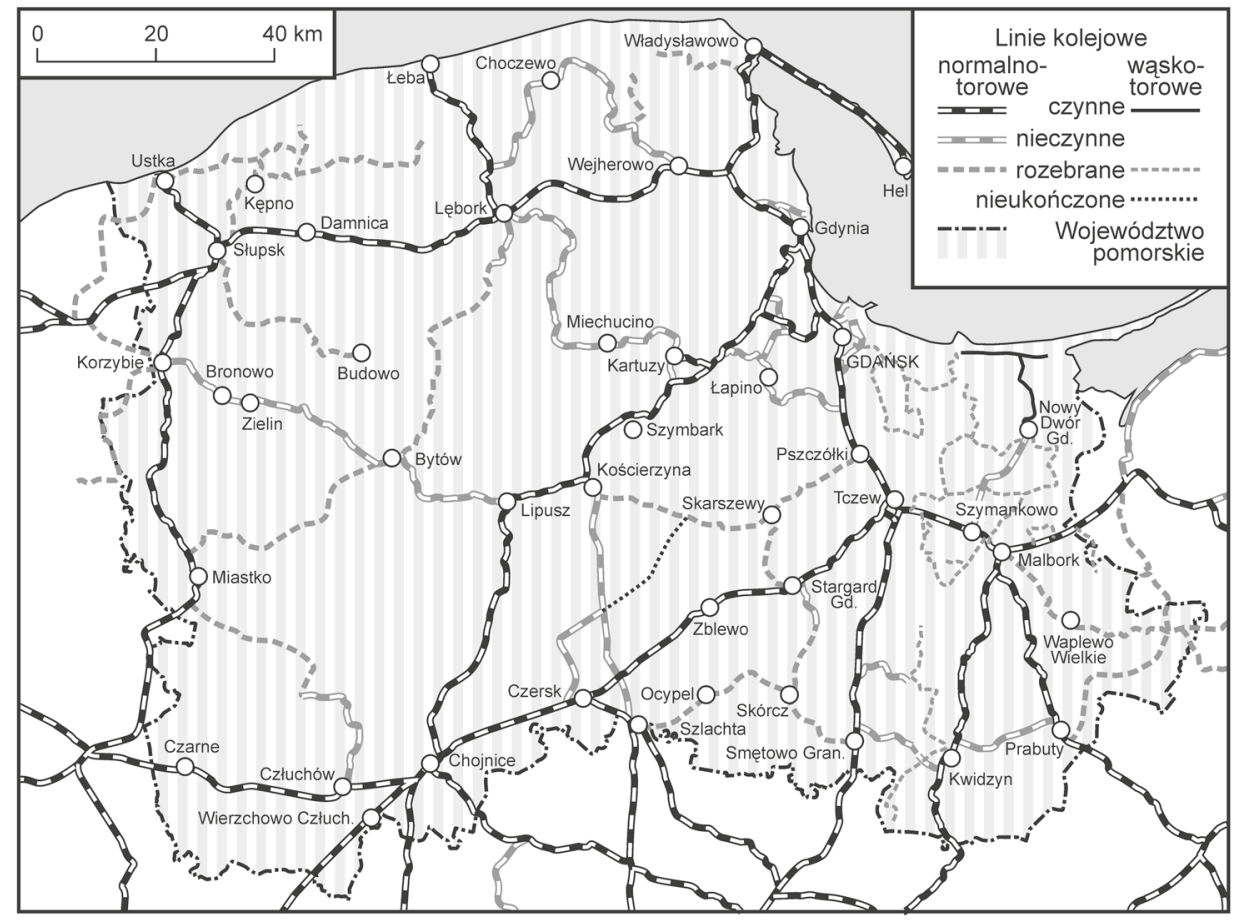

Rysunek 1. Linie kolejowe w województwie pomorskim w 2021 r. Źródło: opracowanie własne

W 1926 r. przerwany został ciąg kolejowy łączący Smętowo i Kwidzyn, które dzieliła wówczas granica państwa przebiegająca na Wiśle. Decyzją władz polskich rozebrano wtedy most kolejowy w Opaleniu Tczewskim, którego przęsła wykorzystano w Toruniu i Koninie. Znaczące ograniczenia ruchu pociągów w województwie pomorskim przyniósł 1945 r., kiedy to bataliony Armii Czerwonej zdemontowały całe linie kolejowe w zachodniej części województwa. Łupem sowietów padła większość linii kolejowych w okolicach Słupska, rozmontowano torowiska łączące Słupsk z Budowem, Słupsk z Dargoleza, Kępno Słupskie z Ustką, Komnino ze Smołdzinem, Sławno z Ustka, Miastko z Bytowem i Lęborkiem, a także Korzybie z Polanowem. Działania Armii Czerwonej widoczne 
były również we wschodniej części województwa, gdzie rozebrano linie wychodzące z węzła kolejowego w Myślicach w kierunku Prabut, Małdyt, Miłomłyna i Elbląga. W latach 70. i 80. XX w. rozpoczął się proces likwidacji kolei wąskotorowych, między innymi z powodu rosnącego ruchu samochodowego i licznych skrzyżowań torów kolejek wąskotorowych z drogami. W 1973 r. na części Żuławskiej Kolei Dojazdowej (ŻKD), położonej na Lewym Brzegu Wisły, doszło do tragicznego w skutkach zderzenia autobusu marki Jelcz z wagonem motorowym MBd1-127, które doprowadziło do zawieszenia ruchu pociągów na lewobrzeżnej części ŻKD z dniem 31 grudnia 1973 r. i rozbiórki torowisk rok później (Bebenow, Strzyżewski, 2018). Decyzją Ministra Komunikacji z dnia 21 maja 1985 r. z dniem 1 stycznia 1986 r. zlikwidowano Kwidzyńską Kolej Dojazdową a przewóz osób i towarów na liniach MarezaRusinowo i Mareza-Gurcz zastąpiono transportem samochodowym. Prace rozbiórkowe na kwidzyńskiej wąskotorówce trwały do $1989 \mathrm{r}$. Najdłużej funkcjonowały połączenia osobowe na prawobrzeżnej części Gdańskiej Kolei Dojazdowej, które ostatecznie zlikwidowano w 1996 r. Na przełomie XX i XXI w., między innymi w wyniku przemian ustrojowych w Polsce, doszło do zapaści w Polskich Kolejach Państwowych (PKP) i ograniczenia ruchu pasażerskiego na niespotykaną wcześniej skalę. Historię likwidacji połączeń pasażerskich na pomorskich liniach kolejowych przedstawiono w tabeli 1.

Tabela 1. Normalnotorowe linie kolejowe województwa pomorskiego o zawieszonym ruchu pociągów pasażerskich

\begin{tabular}{|r|c|c|c|}
\hline Lp. & $\begin{array}{c}\text { Numer } \\
\text { linii }\end{array}$ & Odcinek & $\begin{array}{c}\text { Zawieszenie } \\
\text { ruchu osobowego }\end{array}$ \\
\hline 1 & 218 & Smętowo-Opalenie Tczewskie & $27.11 .1962 \mathrm{r}$. \\
\hline 2 & 234 & Stara Piła-Gdańsk Kokoszki & $1973 \mathrm{r}$. \\
\hline 3 & 235 & Gdańsk Osowa-Gdańsk Kokoszki & $1973 \mathrm{r}$. \\
\hline 4 & 237 & Lębork-Maszewo Lęborskie & $31.05 .1980 \mathrm{r}$. \\
\hline 5 & 263 & Swarzewo-Krokowa & $29.05 .1989 \mathrm{r}$. \\
\hline 6 & 244 & Morzeszczyn-Gniew & $10.07 .1989 \mathrm{r}$. \\
\hline 7 & 256 & Szymankowo-Nowy Dwór Gdański & $10.07 .1989 \mathrm{r}$. \\
\hline 8 & 243 & Starogard Gdański-Skarszewy & $05.11 .1989 \mathrm{r}$. \\
\hline 9 & 413 & Człuchów-Przechlewo & $01.08 .1991 \mathrm{r}$. \\
\hline 10 & 212 & Bytów-Korzybie & $01.08 .1991 \mathrm{r}$. \\
\hline 11 & 418 & Korzybie-Sławno & $01.08 .1991 \mathrm{r}$. \\
\hline
\end{tabular}




\begin{tabular}{|c|c|c|c|}
\hline Lp. & $\begin{array}{c}\text { Numer } \\
\text { linii }\end{array}$ & Odcinek & $\begin{array}{c}\text { Zawieszenie } \\
\text { ruchu osobowego }\end{array}$ \\
\hline 11 & 418 & Korzybie-Sławno & 01.08.1991 r. \\
\hline 12 & 230 & Wejherowo-Garczegorze & 30.05.1992 r. \\
\hline 13 & $230 \mathrm{~A}$ & $\begin{array}{c}\text { Rybno Kaszubskie-Żarnowiec } \\
\text { Elektrownia Jądrowa }\end{array}$ & $30.05 .1992 \mathrm{r}$. \\
\hline 14 & 212 & Lipusz-Bytów & $23.05 .1993 \mathrm{r}$. \\
\hline 15 & 723 & Gdynia Chylonia-Gdynia Rzeźnia & $1993 \mathrm{r}$. \\
\hline 16 & 228 & Gdynia Rzeźnia-Gdynia Port Oksywie & 1993 r. \\
\hline 17 & 229 & Pruszcz Gdański-Stara Piła-Kartuzy & $29.05 .1994 \mathrm{r}$. \\
\hline 18 & 218 & Skórcz-Szlachta & $29.05 .1994 \mathrm{r}$. \\
\hline 19 & 233 & Kościerzyna-Skarszewy & 24.09.1994 r. \\
\hline 20 & 218 & Smętowo-Skórcz & $01.01 .1995 \mathrm{r}$ \\
\hline 21 & 243 & Skórcz-Starogard Gdański & $02.11 .1997 \mathrm{r}$. \\
\hline 22 & 222 & Malbork-Małdyty & $01.10 .1999 \mathrm{r}$. \\
\hline 23 & 218 & Prabuty-Kwidzyn & $01.02 .2000 \mathrm{r}$ \\
\hline 24 & 233 & Skarszewy-Pszczółki & $03.04 .2000 \mathrm{r}$. \\
\hline 25 & 229 & Kartuzy-Lębork & $23.06 .2000 \mathrm{r}$. \\
\hline 26 & 281 & Chojnice-Nakło nad Notecią & $24.06 .2000 \mathrm{r}$. \\
\hline 27 & 249 & Gdańsk Brzeźno-Gdańsk Nowy Port & $15.12 .2002 \mathrm{r}$ \\
\hline 28 & 214 & Somonino-Kartuzy & 01.02.2003 r. \\
\hline 29 & 249 & Gdańsk Główny-Gdańsk Brzeźno & $25.06 .2005 \mathrm{r}$. \\
\hline 30 & 201 & Lipowa Tucholska-Bąk & 2011 r. \\
\hline 31 & 215 & Czersk-Bąk & 19.12.2012 r. \\
\hline 32 & 201 & Bąk-Kościerzyna & 19.12.2012 r. \\
\hline
\end{tabular}

Źródło: opracowanie własne na podstawie danych z portalu Ogólnopolska Baza Kolejowa (2020).

\section{Turystyka koleją}

Uwarunkowania geograficzne województwa pomorskiego w sposób naturalny powoduja, że region ten uznawany jest za atrakcyjny turystycznie. Bogactwo walorów krajobrazowych i kulturowych sprawia, że województwo bardzo często odwiedzane jest przez turystów. Do wielu atrakcyjnych turystycznie miejscowości można dojechać pociągiem, mimo znacznego zmniejszenia gęstości sieci kolejowej województwa. Sztandarowym 
przykładem wykorzystania turystycznego infrastruktury kolejowej jest linia 213, łącząca Redę i Hel. Główną determinantą sezonowego szczytu przewozowego pociągów relacji Gdynia Główna-Hel jest fakt, iż pociąg przejeżdża przez wszystkie znane kurorty nadmorskie położone nad zatoką Gdańską: Puck, Swarzewo, Władysławowo, Chałupy, Kuźnicę, Jastarnię, Juratę i Hel. Z uwagi na ograniczoną przepustowość drogi z Władysławowa do Helu, duża część turystów, którzy zdecydowali się na wypoczynek we Władysławowie, chcąc odwiedzić kurorty położone na Mierzei Helskiej, decyduje się na skorzystanie z transportu kolejowego. Jest to bardzo dobry przykład turystyki koleją a więc wykorzystania pociagu jako środka transportu, za pomocą którego turysta dotrze do miejsca docelowego, gdzie chce skorzystać z oferty turystycznej. W sezonie letnim samorząd województwa pomorskiego uruchamia też dodatkowe pociągi do nadmorskich kurortów w Łebie i Ustce. Duże znaczenie ma również dojazd koleją do Trójmiasta zarówno pociągami regionalnymi, jak i dalekobieżnymi z innych części kraju.

Turysta pragnący odwiedzić pomorskie miejsca kultu religijnego, takie jak: Kalwaria Wejherowska (przystanek osobowy Wejherowo Nanice), Sanktuarium pw. św. Jakuba w Lęborku (stacja Lębork), Sanktuarium Matki Bożej Królowej Rodzin w Kościerzynie (stacja Kościerzyna), Sanktuarium Matki Bożej Królowej Polskiego Morza w Swarzewie (przystanek osobowy Swarzewo), Sanktuarium Matki Bożej Brzemiennej w Gdańsku Matemblewie (przystanek osobowy Gdańsk Brętowo), również może skorzystać z kolei. W województwie pomorskim znajduje się wiele znaczących zabytków: zamek krzyżacki w Malborku (stacja Malbork), zamek w Kwidzynie (stacja Kwidzyn), zamek w Człuchowie (stacja Człuchów), starówka w Chojnicach (stacja Chojnice), młyn wodny w Lipuszu (stacja Lipusz). Jest też wiele atrakcji przyrodniczych: najwyższy szczyt Kaszub (przystanek osobowy Wieżyca), spływy kajakowe rzeką Brdą (stacja Rytel), jezioro Kosobudno (przystanek osobowy Męcikał), jezioro Raduń (przystanek osobowy Raduń), jezioro Garczyn (przystanek osobowy Garczyn), jezioro Ostrzyckie (przystanek osobowy Krzeszna), Bory Tucholskie (przystanek osobowy Męcikał, przystanek osobowy Powałki). Pociągiem dotrzeć można także do miejsc związanych z turystyką wellnes \& spa: Dolina Charlotty (przystanek osobowy Gałęzionowo), Klinika Krojanty (przystanek osobowy Krojanty), Grand Hotel (stacja Sopot). Gęsta sieć punktów turystycznych w województwie pomorskim, do których można dojechać koleją sprawia, że jest to często wybierany środek lokomocji, wykorzystywany $\mathrm{w}$ ruchu turystycznym. 


\section{Turystyczne atrakcje na kolejowych szlakach (turystyka kolejowa)}

Turystyka kolejowa $\mathrm{w}$ województwie pomorskim skupia się $\mathrm{w}$ trzech najbardziej znanych i posiadających najlepszą ofertę turystyczną obiektach i lokalizacjach. Pierwszym obiektem jest stacja Kościerzyna, gdzie znajduje się muzeum kolejnictwa. Historia kościerskiej placówki sięga początku lat 90. XX w. Zarządzeniem dyrektora Północnej Dyrekcji Okręgowej Kolei Państwowych w Gdańsku z dnia 1 listopada 1992 r. na miejscu dotychczasowej lokomotywowni został utworzony Skansen PKP Kościerzyna (fot. 1).

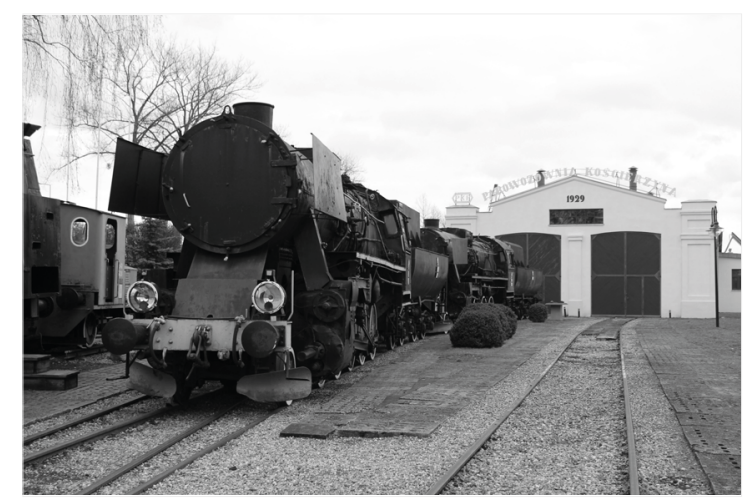

Fotografia 1. Parowóz Ty42-126 przed halą Skansenu Parowozowni Kościerzyna Źródło: D. Otta (2017)

Zadania Skansenu polegały nie tylko na gromadzeniu i konserwacji eksponatów związanych z historią kolei, ale także na utrzymywaniu w stanie czynnym parowozów. Oprócz działalności o charakterze muzealnym Skansen posiadał też czynne parowozy, prowadzące tzw. pociągi retro. W 2001 r., w wyniku restrukturyzacji i przekształceń w Przedsiębiorstwie Państwowym PKP, Skansen został przekazany pod zarząd spółki PKP Cargo. W 2009 r. placówka ta, funkcjonująca już jako Muzeum Kolejnictwa w Kościerzynie, została włączona do Muzeum Ziemi Kościerskiej. Obecnie w kościerskim muzeum można oglądać 47 historycznych pojazdów szynowych w tym 17 parowozów. Do najcenniejszych eksponatów trakcji parowej należą: Ok1-112 - pruski parowóz osobowy serii P8 wyprodukowany w 1915 r., Tw1-90 - pruski parowóz towarowy serii G10 wyprodukowany w $1919 \mathrm{r}$. 
oraz Oi2-29 - niemiecki parowóz osobowy serii BR24 wyprodukowany w 1940 r. (jeden z 4 zachowanych pojazdów tej serii w Europie). Trakcję spalinową $\mathrm{w}$ kościerskim muzeum reprezentują m.in.: SP45-039 - polska lokomotywa pasażerska wyprodukowana w 1974 r., jedyna zachowana lokomotywa serii SP45 oraz prototypowa polska lokomotywa przeznaczona do prowadzenia pociągów pospiesznych - SP47-001. Ciekawostkę stanowi też przedstawiciel trakcji elektrycznej - Elektryczny Zespół Trakcyjny EW90-12, który po wojnie kursował na linii Trójmiejskiej Szybkiej Kolei Miejskiej (SKM), a oryginalnie obsługiwał połączenia berlińskiej S-bahn (Muzeum Kolejnictwa, 2020). Ponadto w Kościerzynie można podziwiać pięknie odrestaurowany zabytkowy dworzec kolejowy oraz powojenną żelbetową wieżę ciśnień.

Kolejnym ważnym punktem dla turystyki kolejowej w województwie pomorskim jest sześciokierunkowa stacja węzłowa w Chojnicach, będąca największym w Polsce niezelektryfikowanym węzłem kolejowym. W pięciu kierunkach uruchamiane są pociągi pasażerskie, zaś ostatnia z linii, wiodąca w stronę Nakła nad Notecia, jest czynna jedynie w ruchu towarowym. Pierwsze pociągi do Chojnic dotarły w $1871 \mathrm{r}$. za sprawą budowy Królewskiej Kolei Wschodniej (Ostbahn), łączącej Berlin i Królewiec (Otta, 2018). Stacja posiada charakterystyczny dla dużych dworców pruskich podział, w którym budynek dworca usytuowany jest między torami na szerokim peronie środkowym tzw. wyspowym. Podobnie zlokalizowane są m.in.: stary dworzec w Poznaniu, dworce w Toruniu, Lesznie, Pile, Krzyżu, Żarach czy Kłodzku, natomiast w innych regionach Polski układ taki jest rzadko spotykany. W Chojnicach po stronie północnej znajdują się dwa perony obsługujące dawny Ostbahn (fot. 2), zaś po stronie południowej trzy perony obsługują ruch regionalny w pozostałych kierunkach (Zakrzewska, 2018). Pomimo upływu lat stacja zachowała historyczny charakter i w całości została objęta opieką konserwatora zabytków. Do najciekawszych obiektów na stacji należy budynek dworca kolejowego z 1873 r., wzniesiony jako piętrowa, wielobryłowa budowla murowana z cegły, nawiązująca do budowli renesansowych. Budynek ma przejścia na perony zaprojektowane na planie krzyża, obszerny hall kasowy we frontowej części oraz salę restauracyjną na tyle i poczekalnię, której kształt architektoniczny przypomina charakterystyczną dla budowli sakralnych wieloboczną absydę, można z niej obserwować całą stację (Zakrzewska, 2018). Dawna siedmiostanowiskowa hala parowozowni obecnie jest wykorzystywana jako wagonownia spółki Polregio. 


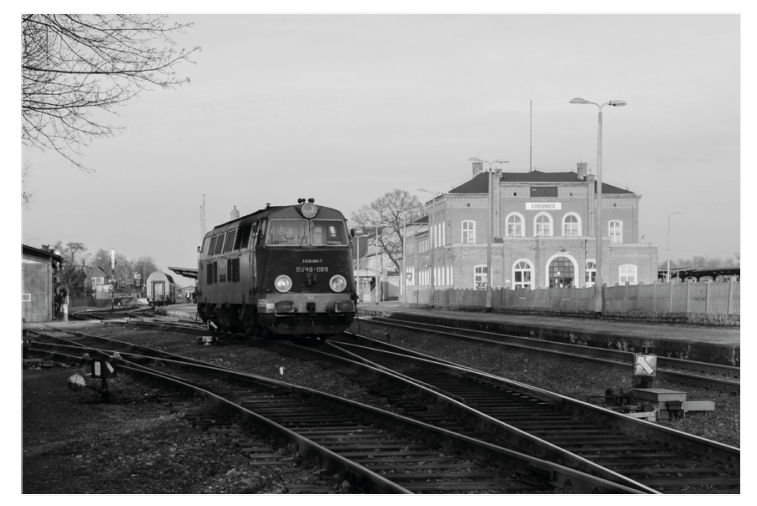

Fotografia 2. Dworzec kolejowy w Chojnicach widziany od strony północnej Źródło: D. Otta (2016)

Interesujące są także: budynek noclegowni drużyn pociągowych oraz dwie wieże ciśnień. Ponadto ciekawostkę stanowią licznie zachowane żurawie do wodowania parowozów oraz zadaszenia peronów i przejść podziemnych.

W Chojnicach znajduje się też Sala Tradycji Kolejowej, prowadzona przez Chojnickie Stowarzyszenie Miłośników Kolei, gromadząca liczne przedmioty związane $\mathrm{z}$ historią kolejnictwa. Na terenie stacji stoi też parowóz Ty2-1387 z 1942 r., ustawiony jako pomnik. Jest to ostatnia w Polsce stacja, będąca zarazem atrakcją chojnickiego węzła, w której Polregio wykorzystuje $\mathrm{w}$ ruchu regionalnym wagony pasażerskie typów 120A oraz piętrowe DBme i lokomotywy spalinowe serii SM42/SU42. Pociagi w klasycznym zestawieniu można spotkać głównie na linii 203 pomiędzy Krzyżem, Piłą, Chojnicami i Tczewem, a w sezonie wakacyjnym również w relacji Chojnice-Trójmiasto-Hel. Ciekawostką dla miłośników kolejnictwa są również znajdujące się w Chojnicach autobusy szynowe serii SA101, SA102 i SA104.

Trzecią z najważniejszych kolejowych atrakcji województwa pomorskiego jest Żuławska Kolej Dojazdowa (ŻKD) - spadkobierca Gdańskich Kolei Dojazdowych (GKD), które ostatecznie zlikwidowano w 1998 r. Dwa lata później członkowie Pomorskiego Towarzystwa Miłośników Kolei Żelaznych (PTMKŻ) wraz z samorządowcami gmin Sztutowo i Stegna podjęli pierwsze rozmowy dotyczące przywrócenia kursowania pociagów na linii dawnych GKD na odcinku Prawy Brzeg Wisły-Stegna-Sztutowo. Do inicjatywy przyłączył się również powiat Nowodworski, po czym zdecydowano o lokalizacji głównego zaplecza odradzającej się kolejki 


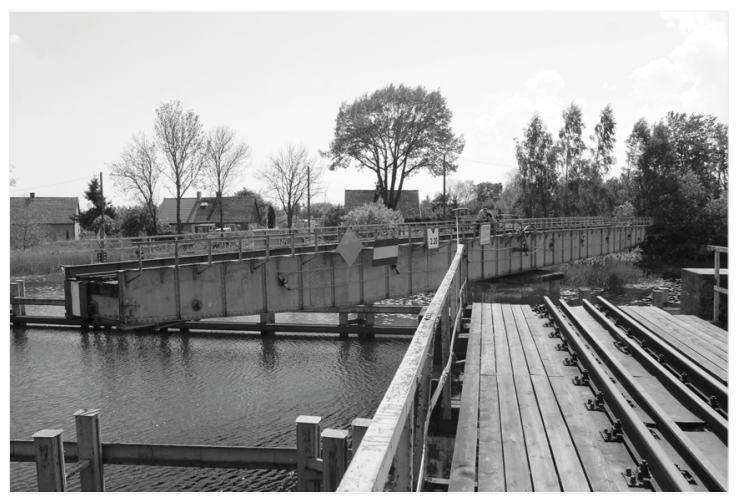

Fotografia 3. Obrotowy most kolei wąskotorowej w pobliżu Rybiny na Żuławach Źródło: D. Otta (2018)

w Nowym Dworze Gdańskim (Bebenow, Strzyżewski, 2018). Pierwszy publiczny kurs przywróconej kolejki odbył się 15 sierpnia 2002 r. na trasie Nowy Dwór Gdański-Stegna. Jednym z najciekawszych pod względem technicznym obiektów na ŻKD jest obrotowy most kolei wąskotorowej z 1906 r., znajdujący się nieopodal miejscowości Rybina (fot. 3). Ta niezwykła budowla hydrotechniczna jest jedynym tego typu czynnym obiektem w Europie (Bebenow, Strzyżewski, 2018).

Warunkiem uruchomienia przewozów było pozyskanie taboru do obsługi połączeń, gdyż cały tabor zlikwidowanych GKD został zezłomowany lub przekazany na inne koleje. Od 2002 r. członkom PTMKŻ udało się sprowadzić do Nowego Dworu Gdańskiego: trzy lokomotywy spalinowe Faur Lxd2, dwa wagony motorowe Faur MBxd2, jedenaście wagonów pasażerskich, osiem wagonów towarowych, osiem wagonów transporterowych, przeznaczonych do transportu wagonów normalnotorowych oraz cztery pojazdy specjalne: drezynę motorową z przyczepka, wagon do oprysku torów i lemieszowy pług odśnieżny (Bebenow, Strzyżewski, 2018).

W województwie pomorskim na miłośników kolejnictwa czeka też wiele innych atrakcji (rys. 2).

Mało znane muzeum kolejnictwa mieści się w Helu - Muzeum Kolei Helskich będące oddziałem Helskiego Kompleksu Muzealnego, które podlega Muzeum Obrony Wybrzeża. Placówkę otwarto w 2013 r., a jej ekspozycja znajduje się wewnątrz jednego z ogromnych, żelbetowych schronów - magazynów amunicyjnych poniemieckiej baterii Schleswig-Holstein. Muzeum ma przypominać historię i rozwój helskich kolei - zarówno linii normalnotorowej zbudowanej w 1921 r., jak i sieci wojskowych kolejek wąskotorowych. 


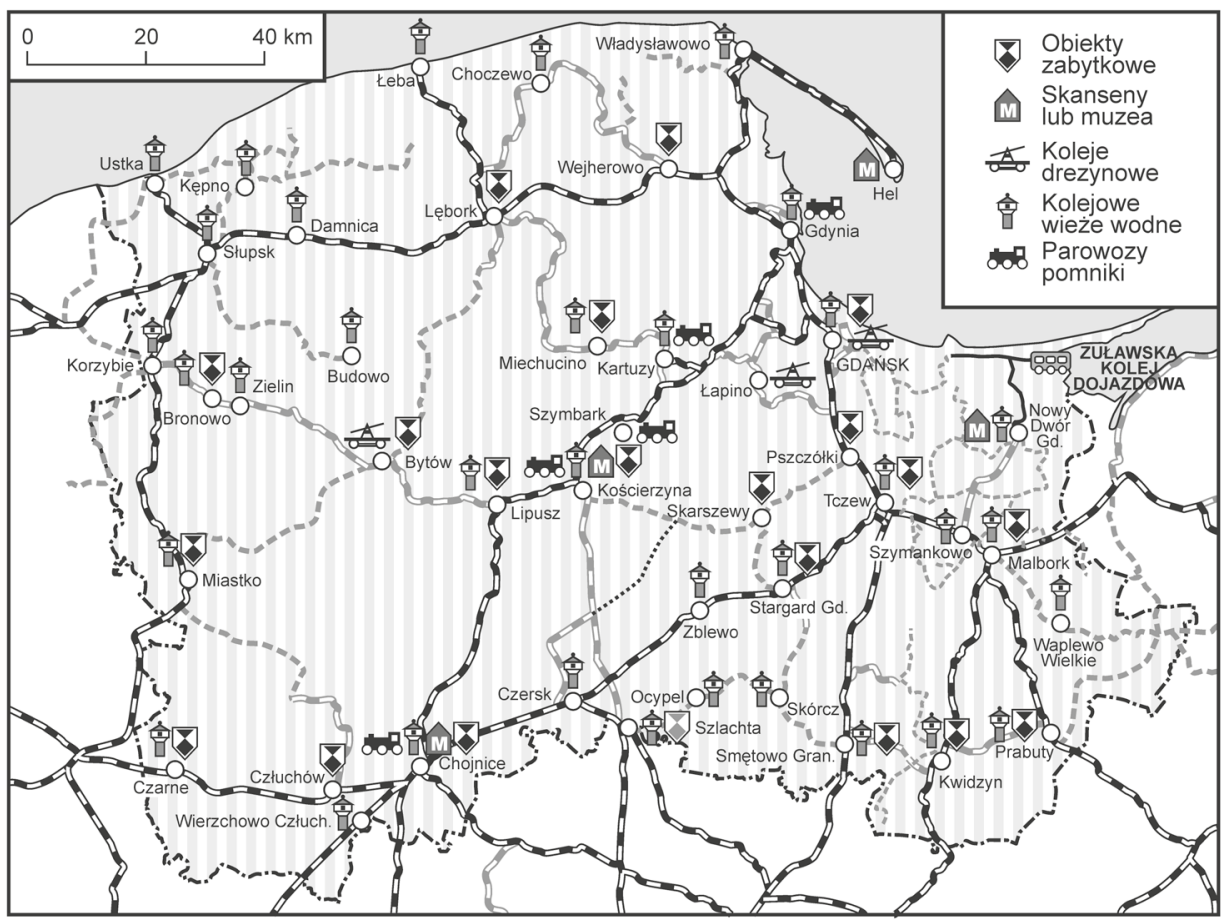

Rysunek 2. Współczesne obiekty turystyki kolejowej w województwie pomorskim Źródło: opracowanie własne

W województwie pomorskim jest też wiele miejsc odpowiednich dla turystów kolejowych pragnących zakosztować bardziej aktywnej formy zwiedzania żelaznych szlaków. Na entuzjastów przejażdżek drezyną czekają cztery trasy, gdzie można skorzystać z tego typu rozrywki. Najdłuższy odcinek udostępnia Słupska Powiatowa Kolej Drezynowa (SPKD), której siedziba mieści się we wsi Bronowo, położonej przy nieczynnej obecnie linii kolejowej nr 212. Drezyną SPKD można pokonać niemal 20-kilometrową trasę pomiędzy stacjami Korzybie i Zielin Miastecki. Kolejny odcinek linii nr 212 można przejechać drezyną pasjonatów z Kolei Drezynowej w Bytowie. Bytowską drezyną przemierza się ponad 10-kilometrowy odcinek z Bytowa do wsi Jutrzenka. Od 2003 r. na nieczynnym odcinku linii kolejowej nr 229, pomiędzy Łapinem a Kolbudami, można przejechać się drezyną rowerową. Jeżeli jednak ktoś nie czuje się na siłach, by pokonać tak długie dystanse, to krótkie przejażdżki możliwe są w Gdańsku na półwyspie Westerplatte.

Na entuzjastów architektury kolejowej w województwie pomorskim czekają prawdziwe perełki w postaci dworców kolejowych, takich jak: 
neogotycki dworzec w Malborku z 1890 r., renesansowy gmach dworca głównego w Gdańsku wybudowany w latach 1894-1900 (Masłowski, 2009), neogotycki dworzec w Kwidzynie z 1901 r. Ciekawostkę stanowi również budynek dworca głównego w Gdyni, wzniesiony w latach 1955-1958, będący mieszanką powojennego modernizmu i socrealizmu. Do najstarszych dworców w województwie należą m.in. dworce w Wejherowie i Lęborku na linii z Gdańska do Szczecina, a także w Chojnicach, Czersku i Starogardzie Gdańskim na linii Królewskiej Kolei Wschodniej, powstałe w latach 70. XIX w. Pozostałością po zlikwidowanych liniach kolejowych są okazałe dworce kolejowe w Skarszewach i Skórczu (Ogólnopolska Baza Kolejowa, 2020). Do czasów obecnych zachowało się też wiele wież wodnych, które dawniej były obecne na niemal każdej większej stacji kolejowej. Najciekawsze historyczne obiekty tego typu znajdują się na stacjach w Słupsku, Korzybiu, Miastku, Czersku i Chojnicach. W przypadku Kępna, Budowa i Waplewa Wielkiego stare zrujnowane wieże wodne są obok nasypów, jedynymi pozostałościami po istniejących tam niegdyś liniach kolejowych. Intersującym obiektem turystycznym jest dawna stacja kolejowa w Miechucinie, sprawiająca wrażenie jakby czas zatrzymał się tam w miejscu. Budynki, torowiska i urządzenia sterowania ruchem kolejowym pozostały tam nietknięte od momentu, gdy stację opuścił ostatni pociąg i cały obiekt porosły drzewa, tworząc niezwykłą scenerię.

Miłośnicy taboru kolejowego oprócz zbiorów Skansenu w Kościerzynie mogą też oglądać lokomotywy ustawione jako pomniki historii: w Chojnicach parowóz Ty2-1387, w Szymbarku Ty2-921, w Kartuzach Ty2-14, w Gdyni Grabówku OK127-27 oraz Tkt48-170 i Tkh49-11 w Tczewie (Czarnecki, 2020).

\section{Podsumowanie}

W województwie pomorskim jest wiele obiektów istotnych zarówno dla turystyki kolejowej, jak i turystyki koleją. Obydwie te dziedziny w ostatnich czasach zyskują na popularności, a pomorskie ma duży potencjał turystyczny, który można wykorzystać w promowaniu regionu oraz zachęcaniu miłośników kolei do jego odwiedzania. Dzięki zaangażowaniu samorządu województwo już dziś jest liderem w rozwoju kolei, z najwyższym w kraju odsetkiem podróży koleją w przeliczeniu na jednego mieszkańca. 


\title{
Bibliografia
}

Bebenow, F., Strzyżewski, P. (2018). Żuławska Kolej Dojazdowa. Kraków: Wytwórnia Grafiki Jarosław Bytner.

Czarnecki, T. (2020). Wykaz zachowanych w Polsce parowozów normalnotorowych. Pobrane z: http://www.polskieparowozy.pl/index2.php?wykaz=1435 (22.08.2020).

Górny, J. (2014). Uwarunkowania rozwoju turystyki kolejowej w województwie wielkopolskim. W: P. Krąż (red.), Wspótczesne problemy i kierunki badawcze w geografii. Tom 2 (s. 17-31). Kraków: Instytut Geografii i Gospodarki Przestrzennej Uniwersytetu Jagiellońskiego.

Masłowski, A. (2009). Dworzec Główny w Gdańsku. Pobrane z: https://ibedeker.pl/bez-kategorii/dworzec-glowny-w-gdansku/ (22.08.2020).

Muzeum Kolejnictwa (2020). Pobrane z: https://muzeumkolejnictwa.com.pl (22.08.2020). Ogólnopolska Baza Kolejowa (2020). Pobrane z: https://www.bazakolejowa.pl/index.php (22.08.2020).

Otta, D. (2018). Po kolei o chojnickiej kolei. Chojnice: Miasto Chojnice.

Rogalewski, O. (1974). Zagospodarowanie turystyczne. Warszawa: Wydawnictwo Szkolne i Pedagogiczne.

Tarski, I. (1973). Definicja transportu. Przeglad Komunikacyjny, 12, 18-22.

Zakrzewska, M. (2018). Program prac konserwatorskich dla elementów zabytkowych budynku administracyjnego. Gdańsk: „PROLITHOS” Konserwacja zabytków Leszek Zakrzewski.

\section{TURYSTYKA KOLEJOWA W WOJEWÓDZTWIE POMORSKIM}

\begin{abstract}
Abstrakt: Turystyka kolejowa i turystyka koleją to dwa nieczęsto spotykane w literaturze zagadnienia. W niniejszym tekście przedstawiona została krótka definicja obydwu pojęć, rozszerzona o przykłady funkcjonowania tych gałęzi turystyki w województwie pomorskim. Sieć kolejowa tego województwa w większości została wybudowana za czasów zaboru pruskiego, była dość gęsta i zaspakajała ówczesne potrzeby komunikacyjne społeczeństwa. Zawierucha po II wojnie światowej, a także przemiany gospodarcze przełomu wieków spowodowały znaczne uszczuplenie sieci kolejowej województwa, wykorzystywanej do prowadzenia ruchu pociągów. Linie kolejowe, które przetrwały do dziś i są wykorzystywane w ruchu pasażerskim, umożliwiają turystom dojazd do atrakcji turystycznych położonych na terenie województwa pomorskiego, a więc zapewniają uprawianie turystyki koleją. Natomiast linie i budowle kolejowe, które przestały spełniać rolę komunikacyjna, stały się obiektami wykorzystywanymi w turystyce kolejowej. Na terenie Pomorza Gdańskiego znajdują się również skanseny i muzea kolejnictwa, w których turyści mogą zapoznać się z historią kolei w regionie. Aktywne spędzanie czasu w kolejowym klimacie umożliwiają przejazdy drezynami oraz kolejką wąskotorową.
\end{abstract}

Słowa kluczowe: turystyka koleją, turystyka kolejowa, transport kolejowy, województwo pomorskie.

\section{RAIL TOURISM IN THE POMERANIAN VOIVODSHIP}

Abstract: Rail tourism and tourism by rail are two issues that are rarely encountered in the literature. This text presents a short definition of both terms, extended by examples of their functioning in the Pomeranian Voivodeship. The railway network of this voivodeship, 
built mostly under Prussian rule, was quite dense and satisfied the communication needs of the society. World War II, and later the economic changes at the turn of the present century, caused a significant reduction in the railway network. Railway lines, which have survived to this day and used for passenger traffic, allow tourists to reach tourist attractions located in the Pomeranian Voivodeship, and thus foster tourism by rail. On the other hand, lines and structures which ceased to fulfill a communication role, have become sites used in railway tourism. There are also open-air museums and railway museums in the Gdańsk-Pomerania district where tourists can learn about the history of railways in the region. The active spending of time in a railway atmosphere is possible thanks to trolley rides and a narrow-gauge railway.

Keywords: tourism by rail, rail tourism, railway transport, Pomeranian Voivodeship. 